\title{
Prof. Krzysztof Warzocha laureatem Wektora 2013
}

Decyzją Kapituły Pracodawców Rzeczypospolitej Polskiej prof. Krzysztof Warzocha Dyrektor Centrum Onkologii - Instytutu im. Marii Skłodowskiej-Curie został laureatem nagrody Wektor 2013. Pracodawcy Rzeczypospolitej Polskiej (dawniej Konfederacja Pracodawców Polskich) działa od 1989 roku, reprezentuje ok. 10 tys. firm zatrudniających ok. 5 mln pracowników.

Wedle uzasadnienia:„Nagroda przyznawana jest osobistościom wyróżniającym się kompetencją, przedsiębiorczością, innowacyjnością i aktywnością, a także determinacją w tworzeniu lepszej jakości życia gospodarczego.

Wektory dla Centrum Onkologii - Instytutu im. Marii Skłodowskiej-Curie w Warszawie przyznano za nowe kierunki w zarządzaniu w obszarach: medycznym, organizacyjno- -prawnym i finansowym. Efektem wprowadzonych zmian jest pełna realizacja programu naprawczego w postaci:

- wzrostu przyjmowanych pacjentów do hospitalizacji -5 tys. w skali roku,

— wzrostu wykorzystania łóżek o $17 \%$ z 57 do $74 \%$ w skali roku,

- wzrostu przyjmowanych pacjentów pierwszorazowych z 20 tys. do 49 tys. - wzrost o 29 tys.

- wzrostu środków finansowych z NFZ z realizacji kontraktu za 2013 r. (wobec 2012 r.) o 41 mln zł (wynik finansowy dodatni $+14 \mathrm{mln})$,

- wzrost przychodu w klinikach — wzrosły o 35\%, a bloku operacyjnego o $12 \%$,

— outsourcing kuchni (oszczędności w skali roku 2,5 mln zł)".

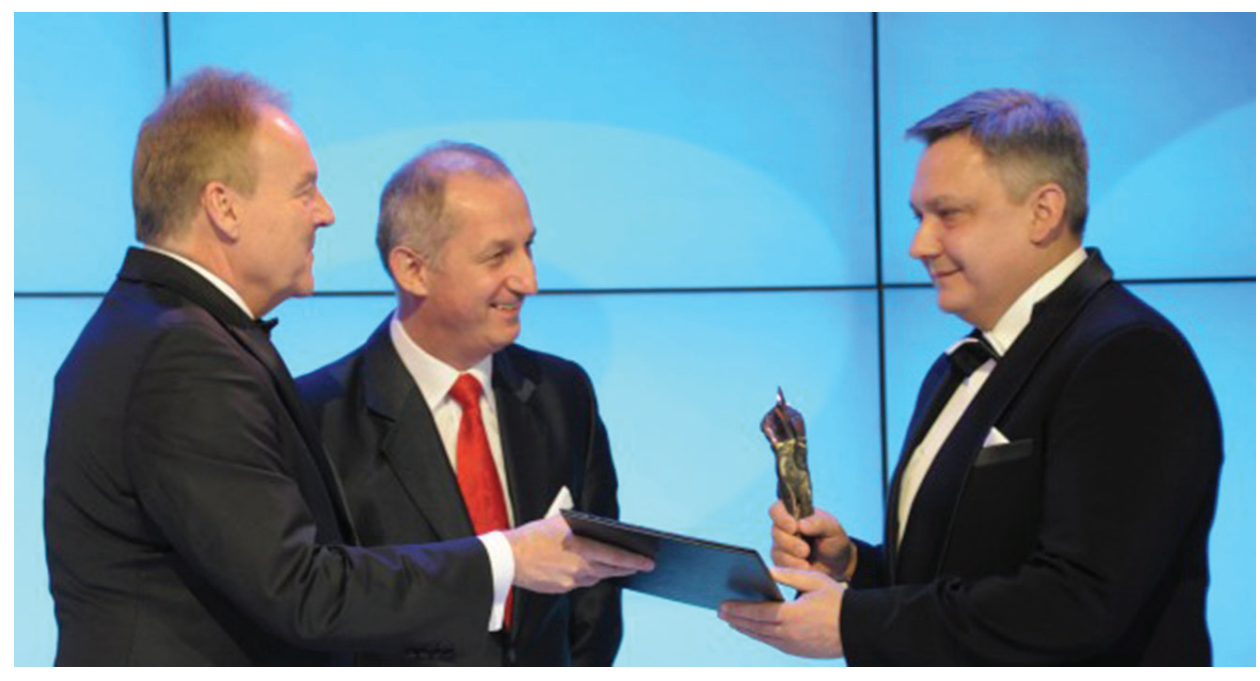

Prof. Krzysztof Warzocha, dyrektor CO-I odbiera nagrodę Wektory 2013 z rąk Andrzeja Malinowskiego, Prezydenta Pracodawców RP oraz wiceministra zdrowia Sławomira Neumanna (fot. Pracodawcy RP) 